UDC 81.373.43

DOI https://doi.org/10.32841/2409-1154.2020.46-2.26

Sandyha L. O.,

$P h . D$. in Linguistics,

Assistant Professor at the Department of Foreign Languages

of the Faculty of Economics

Taras Shevchenko National University of Kyiv

Sviatiuk Yu. V.,

$P h . D$. in Linguistics,

Associate Professor at the Department of Foreign Languages

of the Faculty of Economics

Taras Shevchenko National University of Kyiv

\title{
ENGLISH NEOLOGISMS IN TOURISM
}

Summary. The article investigates the English neologisms coined in the sphere of tourism as a complex phenomenon and their word-formation types. Neologisms are defined as newly coined lexemes or word combinations or the existing words which acquired a new meaning that name new phenomena and are moderately used by most speakers of a given language. Despite a wide array of researches in neology, the problem of neologisms' investigation is topical due to their absolute novelty, especially when it concerns the study of a particular sphere in which neologisms are born.

With regard to the fact that modern people sometimes lack time for long holidays and at the same time desire unusual and non-standard trips and accommodation while travelling, a wide range of new non-traditional ways of travelling have emerged. Therefore, the focus of our research is on the neologisms which nominate new types of non-standard holidays (astrotourism, wall crawl, daycation, nakation, heritage travel, DNA trip), family holidays (greycation, maternymoon, landmarkation), tourists (randonaut, begpacker), modern types of hotels (poshtel, bubble hotel) and the adjacent phenomena (mistake fare, flight shaming, undertourism, overtourism). The emphasis is also laid on the study of the neologisms denoting new types of holidays which have appeared as a result of the Covid-19 pandemic (air bridge, corona corridor, travel bubble).

The neological coinages for this research were selected by means of sampling from electronic lexicographic sources and reputable Internet sites.

The derivational characteristics of the neologisms at issue are also in the focus of our attention. The word-forming mechanisms which take part in the neologisms' formation, namely affixation, blending, and compounding are studied. Within the framework of the research blending turned out to be the most productive word-forming mechanism ( $47 \%$ of the neologisms from the sampling), with compounding coming second with $43 \%$ of the neologisms under investigation. Affixation was discovered to be the least productive word-forming mechanism accounting for the remaining $10 \%$ of the sampling.

General conclusions are made at the end of the article and suggestions for further neological researches are offered.

Key words: neologism, blending, compounding, affixation.

Problem statement. It would be no exaggeration to say that the modern world is changing at a pace never seen before. Modern people are always on the search for something new, be it a new technology, a new kind of entertainment, or a new type of holiday. The variety of the latter has become so abundant, that a new array of neologisms has emerged to name them. The neological coinages in this sphere have not been researched as a complex phenomenon yet due to their absolute novelty. Thus, such new holiday practices and phenomena denoted by corresponding neologisms are the object of current research.

Analysis of recent research and publications. Neologisms have always been considered interesting objects of research by a multitude of linguists worldwide, namely J. Algeo, A. Lehrer, K. Maxwell, A. Metcalf, P. Hohenhaus, R. Fischer, B. Aarts and A. Mcmahon, K. Karpova, Yu. Zatsnyi, M. Shutova, L. Sandyha and many others. For instance, R. Fischer [5], Yu. Zatsnyi [2], M. Shutova [1] researched neologisms comprehensively in the English language, neological word-formation techniques were investigated by A. Lehrer [8], L. Sandyha et al. [11] researched English neologisms in different spheres, for instance, in the sphere of ecology.

There are still numerous challenges neologisms are facing, for instance, what the difference between a neologism and a nonceword is, how many times a neologism must be used and how long it takes for it to become fixed in a dictionary etc.

In the framework of this research neologisms are defined as 'newly coined or existing words or word combinations which name new concepts or phenomena and which are moderately used by most representatives of a given society' [11].

The aim of the article is to study the neologisms coined in the sphere of tourism as a complex phenomenon, as well as their word-formation types.

Presentation of the main material. Within the framework of our research 47 neologisms nominating new types of holidays, tourists, hotels and the adjacent phenomena were selected by sampling from the following lexicographic sources: About Words Cambridge Dictionaries Online Blog [3] and Buzzword Archive Macmillan Dictionary [4]. The neologisms at issue have also been taken from reliable Internet sites, namely www.telegraph.co.uk, https://www.theaustralian.com.au.

The research methods were selected on the basis of the aim, objectives of the study and the accumulated data. Therefore, the following linguistic methods were employed: 1) semantic analysis (to analyze the lexical meanings of the neological vocabulary under 
investigation); 2) descriptive method (to describe the neologisms at issue and define their similarities and differences); 3) structural analysis (to investigate the derivational potential of the neologisms naming new touristic phenomena; to study blending, compounding and affixation as productive word-formation techniques in forming touristic neologisms; 4) statistical method (to calculate the neologisms and classify them into word-formation groups).

As it has already been mentioned, a lot of modern people desire to spend their vacations in an unusual way. Traditional seaside or mountain holidays might seem boring and old-fashioned for certain individuals who choose to go on a trip to some unusual destination. For instance, some people may prefer to travel to the places where outer space natural phenomena can be seen clearly, for example, stars, eclipses, rocket launches etc., which is denoted by the neologism astrotourism (prefixation) [3].

Graffiti and art lovers might opt for a wall crawl (compounding) [3], the type of travelling which involves visiting different walls in a town or city to enjoy the murals or other forms of street art on them.

Fans of planes choose air cruises (compounding) [3], i.e. air journeys during which passengers can enjoy panoramic air views or engage in fun activities during the flight.

While air cruises cost a fortune, some passengers may be lucky to get a ridiculously cheap plane ticket as a result of a mistake on an airline's website, the price being called mistake fare (compounding) [3].

The ecological aspect of travelling has become the apple of discord in the world recently, thus sometimes holidaymakers who choose travelling by air may face flight shaming (compounding) [3], i.e. come under harsh criticism for using planes to reach their destination as the latter cause substantial damage to the environment.

Modern technologies can also be used to help travelers choose a location for their trips. For instance, randonauts (blending random + astronauts) [3] make computer bots generate a random location for their trips hoping to have an extraordinary holiday, the activity itself being called randonauting (suffixation) [3].

The holidaymakers who engage in heritage travel (compounding) [3] or go on a DNA trip (compounding) [3] visit the places where their ancestors used to live to find out more about them.

Adepts of Islamic Sharia laws can choose halal holidays (compounding) [12] during which they may have their pork-free meals in alcohol-free dining areas, stay in hotels with prayer rooms or hotels located not far away from mosques, attend single sex facilities, receive guidance in their hotel rooms on the direction of Mecca.

Sometimes people engage in tattoo tourism (compounding) [12], i.e. travel in search of the most talented tattoo artists to decorate their bodies.

The lexeme 'vacation' has become a part of several more neological blends. Firstly, there is a certain category of modern businesspeople who can't afford to have a proper rest; therefore, they continue to work even on holiday. Sometimes such workaholics book a hotel or other accommodation and work from there, which is called a workation (blending work + vacation) [12] or a fake-ation (blending fake + vacation) [12].

A new type of a short holiday called daycation (blending day + vacation) [3] has come into existence. A daycation denotes a trip to a resort or a hotel where people spend the whole day after which they return home in the evening.
Some people may achieve relaxation spending a holiday without having to wear clothes most of the time, thus a neologism nakation (blending naked + vacation) [3] has been born.

There also exist mancations (blending naked + vacation) [12] which are male-only holidays, haycations (blending hay + vacations) [12] which denote holidays spent on a farm, a staycation (blending stay + vacation) [12] is a holiday which is spent at home or the one which does not presuppose travelling abroad, playcation (blending play + vacation) [12] denotes a holiday during which people want to enjoy themselves.

A greycation/graycation (blending grey/gray + vacation) [4] is a family holiday which three or more generations of one family spend together. On the one hand, parents of small children may relax and have a night off while grandparents spend time with their grandchildren, on the other hand, it is sometimes a chance to share costs and thus save money.

There are some holiday destinations or cities though which don't receive enough tourists, thus the local hospitality industry is suffering losses, the phenomenon being called undertourism (prefixation) [3]. By contrast, some holiday destinations welcome too many tourists, which cause frustration and numerous inconveniences for the local population despite the financial benefits, the phenomenon being called overtourism (prefixation) [3].

For some individuals travelling with a purpose of supporting the local sphere of tourism is a matter of choice, which is denoted by the neologism philantourism (blending philanthropy + tourism) [3]. On the other hand, sometimes people travel to other countries with the intention of breaking into people's homes to steal their belongings which is called burglary tourism (compounding) [3].

There is also a new category of Western travelers called begpackers (blending beg + backpackers) [4], who can't fund their continuing journeys and beg for money from local citizens in much poorer countries, the phenomenon itself being called begpacking (blending beg + backpacking) [4].

A special type of a family holiday trip when a mother is on her maternity leave from work is denoted by a neologism maternymoon (blending maternity + honeymoon) [3]. One more new type of holiday taken by a large group of people, in most cases by a family, with the intention to celebrate one of the member's significant birthdays is called landmarkation (suffixation) [3].

On the other hand, some people travel to other countries not to go sightseeing or relax, they might want to take advantage of the divorce laws of a different country which is denoted by the neologism divorce tourism (compounding) [3].

Some individuals may go to a different country to sue, which is called libel tourism (compounding) [12]. Another phenomenon that is on the increase is medical tourism (compounding) [12], which refers to people travelling abroad to undergo cheaper medical treatment or the one which is unavailable or forbidden in their home countries. The examples of medical tourism are, amongst many, fertility tourism (compounding) [12] and stem-cell tourism (compounding) [12].

Extreme lovers may choose disaster tourism (compounding) [12], i.e. visiting places where natural hazards and disasters take place. Rucinska and Lechowicz state that it is tension and emotions that are a natural state of a human psyche that drive those in search of such perilous adventures [10, p. 17]. For example, when the Icelandic volcano Eyiafjallojokull erupted in 2010 many air passengers were unwillingly forced to 'enjoy' a volcation (blending volcano + vacation) [12] being stranded in airports because of the hazard. 
On the contrary, some individuals may choose glamping (blending glamorous + camping) [12] which represents a new type of glamorous holidaymaking which can take a multitude of forms. On the one hand, travelers may stay in luxuriously-equipped tents, yurts, tepees, or vans on glampsites (blending glamorous + campsites) [12]. On the other hand, some people can opt for flashpacking (blending flashy + backpacking) [7], i.e. travelling the world with a backpack in which electronic gadgets - laptops, tablets and smartphones - are a must as flashpackers (blending flashy + backpackers) [7] will be posting photos and videos about their experiences in their social networks and blogs.

Talking about trailblazing types of hotels where modern people like to stay, one should mention a poshtel (blending posh + hotel) [3] which offers its visitors extremely luxurious accommodation, and a bubble hotel (compounding) [3] which has spherical rooms made of transparent plastic or glass.

The world pandemic of Covid-19 has led to considerable changes in people's lifestyles, one of the latter being decreased people's travelling experiences worldwide. For numerous worldwide citizens homecations (blending home + vacation) [3], i.e. vacations spent entirely at home, have become the only available option due to the limitations imposed by the world pandemic.

Coronavirus has become a source of two other neologisms denoting new ways of travelling: air bridge and corona corridor (both compounding) [3]. Air bridge denotes the route between two countries where Covid-19 is under control, thus the citizens of both countries do not go into quarantine upon arrival. Corona corridor in its turn is the neologism with a similar meaning, however, there is no limitation as to the number of countries passengers can travel through to arrive at a certain destination during the Covid-19 pandemic, moreover, the means of transport can be different.

A "travel bubble" (compounding) [9] is the neologism denoting the territories of New Zealand and Australia in which the citizens of both countries can travel during the world pandemic to stimulate the hospitality industries of the two countries.

Moreover, those British citizens who have been inoculated against Covid-19 could have a stamp in their passports called a vaccine stamp [6] which would prove the fact of inoculation. The stamps will be used to accelerate the travelers' checking-in procedures at the airport once the travel industry resumes its operations in the middle of 2021 as the pandemic diminishes. The Department of Transport of the UK believes the stamps will help regenerate the aviation industry by providing travelers with some sort of certainty with regard to coronavirus [4].

Conclusions. The sphere of tourism has become a cradle of numerous neologisms denoting new types of holidays and holidaymakers, modern kinds of hotels and the adjacent phenomena. Changes in people's preferences and lifestyles, the lack of work-life balance for some individuals, social media platforms, ecological initiatives as well as Covid-19 have all stimulated the appearance of a number of neological coinages in tourism. The study showed that the most productive formation methods of the neologisms coined in the aforementioned sphere are blending (47\%), compounding $(43 \%)$, and affixation (10\%).

Our future researches will be devoted to other productive spheres in which English neologisms are coined, in particular social networking, new types of food, economic developments, cultural phenomena etc. Conversion, clipping, and acronym will also be studied as word-forming patterns of modern neologisms.

\section{References:}

1. Зацний Ю. Способи та механізми створення лексико-фразеологічних інновацій англійської мови (2009-2019рр.). Нова філологія. 2020. Вип. 79. С. 20-26.

2. Шутова М. Неологізми в сучасній англійській мові. Науковий вісник кафедри Юнеско КНЛУ. Серія: Філологія. Педагогіка. Психологія. 2010. Вип. 21. С. 79-85.

3. About Words - Cambridge Dictionaries Online Blog (n. d.). URL: https://dictionaryblog.cambridge.org.

4. Buzzword Archive - Macmillan Dictionary (n. d.). URL: http://www. macmillandictionary.com/buzzword/entries/legsie.html.

5. Fischer R. Lexical change in present-day English: a corpus-based study of the motivation, institutionalization, and productivity of creative neologisms. Tubingen, Germany : Gunter Narr Verlag Tubingen, 1998.

6. Hope C. Britons to get 'vaccine stamps' in their passports before overseas travel. 2020. URL: https://www.telegraph.co.uk/politics/2020/11/28/ britons-get-vaccine-stamps-passports-overseas-travel.

7. Kurosawa S. The last word on neologisms in travel and tourism. 2015. URL: https://www.theaustralian.com.au/travel/the-last-word-onneologisms-in-travel-and-tourism/news-story/b2dcbdad59f8585f21d3 899395dflb22.

8. Lehrer A. Neologisms. Encyclopedia of language and linguistics / K. Brown (ed.). $2^{\text {nd }}$ ed. P. 590-593. Oxford, England : Elsevier, 2006.

9. Olmstead M. New Zealand's "Bubble Concept" Is Slowly Letting People Socialize Again. Would It Work in America? 2020. URL: https://slate.com/ news-and-politics/2020/05/new-zealand-quarantinebubble-concept-america.html.

10. Rucinska D., Lechovicz M. Natural Hazard and Disaster Tourism. Miscellania Geographica. 2014. № 18. P. 17-25.

11. Sandyha L., Oliinyk I., Sviatiuk Yu. English green neologisms reflecting new trends in sustainable development. Vcheni zapysky Tavriiskoho natsionalnoho universytetu imeni V.I. Vernadskoho. Seriia: Filolohiia. Sotsialni komunikatsii. - Volodymyr Vernadsky Scientific notes of Tavriia National University. Philology. Social communications. 2020. № 31(70). P. 187-192.

12. Walter L. The holiday of a lifetime? New words for new types of travel. 2012. URL: https://ictionaryblog.cambridge.org/2012/10/29/ the-holiday-of-a-lifetime-new-words-for-new-types-of-travel.

Сандига Л. О., Святюк Ю. В. Англійські неологізми у сфері туризму

Анотація. У статті розглянуто англійські неологізми, утворені у сфері туризму, та способи їх формування. Неологізми визначаються як нові лексеми та словосполучення або такі, що вже існували у мові та отримали нове значення, що позначають нові поняття та помірно використовуються більшістю мовців у певному соціумі. Незважаючи на чималу кількість досліджень у сфері неології, проблема аналізу неологізмів завжди є актуальною, особливо коли йдеться про комплексне дослідження окремої сфери функціонування неологічних одиниць.

3 огляду на те, що сучасні люди подекуди мають менше часу на відпочинок, при цьому відпочивальники стають більш вибагливими та прагнуть незвичайних відпусток та перебування у нестандартних готелях та локаціях, з'явилась велика кількість нових нетрадиційних способів відпочинку. Таким чином, у фокусі дослідження перебувають неологізми у сфері туризму, що позначають нові різноманітні види незвичних подорожей (astrotourism, wall crawl, daycation, nakation, heritage travel, DNA trip), сімейних відпусток (greycation, maternymoon, landmarkation), відпочивальників (randonaut, begpacker), сучасні види готелів (poshtel, bubble hotel) та суміжні явища (mistake fare, flight shaming, undertourism, overtourism). Увага також приділя- 
ється неологізмам, які називають нові види відпочинку, що з'явилися на тлі пандемії коронавірусу (air bridge, corona corridor, travel bubble).

Виокремлення неологізмів у сфері туризму для цієї неологічної розвідки відбувалось шляхом суцільної вибірки 3 електронних лексикографічних джерел та відомих інтернет-сайтів.

У розвідці також робиться акцент на дослідженні словотвірного потенціалу неологізмів, утворених у сфері туризму, зокрема вивчаються такі словотвірні механізми, як словоскладання, афіксація та телескопія. Аналіз маси- ву неологізмів, утворених у сфері туризму, показує, що більшість досліджуваних одиниць (47\%) була утворена за допомогою телескопії. Шляхом словоскладання було утворено 43\% проаналізованих неологізмів. Встановлено, що найменш продуктивним способом формування неологізмів у сфері туризму є афіксація (10\% неологізмів вибірки).

Наприкінці статті зроблено загальні висновки й представлено пропозиції щодо подальших неологічних досліджень.

Ключові слова: неологізм, телескопія, словоскладання, афіксація. 